Fish Diseases and Management, Dept. of Animal Medicine, Faculty of Veterinary Medicine, Assiut University.

\title{
VIBRIOSIS IN NILE TILAPIA, OREOCHROMIS NILOTICUS, AND SUSCEPTIBILITY OF CATFISH, CLARIAS GARIEPINUS
}

(With 2 Tables and 3 Figures)

\section{By}

\section{A. A. ELKAMEL, AYA G. SAAD EL-DEEN* and S.M. AFIFI**}

*Animal Health Research Institute, Assiut Laboratory

** Department of Pathology, Faculty of Veterinary Medicine, Assiut University (Received at 14/9/2011)

مرض الفيبريو فى أسماك البلطى النيلى وحساسية القراميط الأفريقية للعدوي

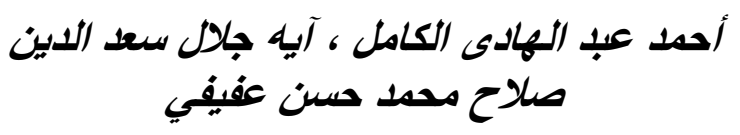

إن الهدف من هذا البحثث هو دراسة مرض الفيبريو في أسماك البلطي النيلي، وضـراوة

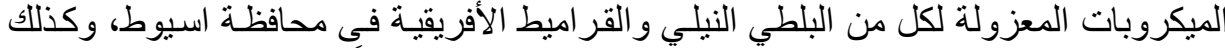

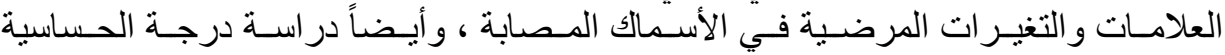

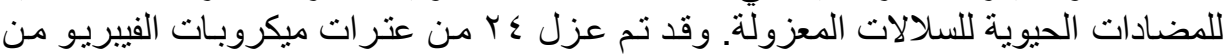

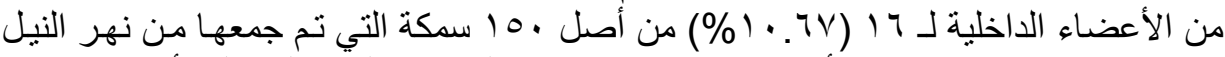

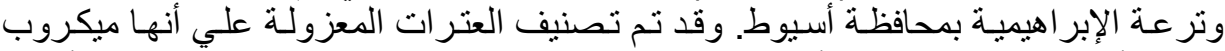

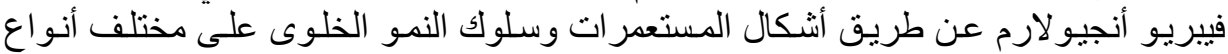

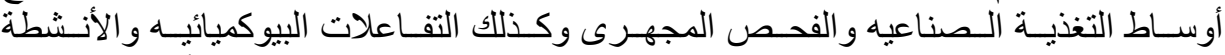

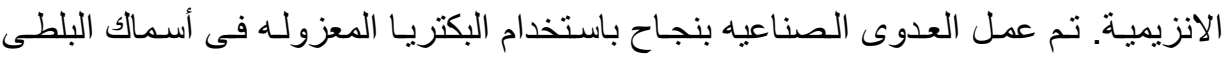

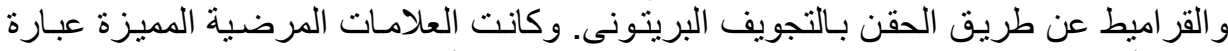

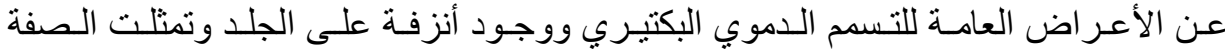

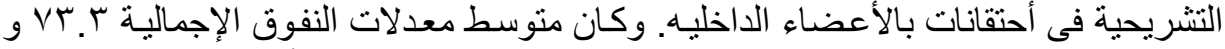

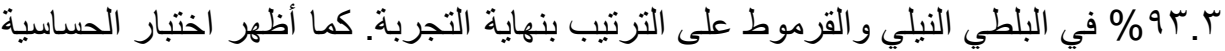

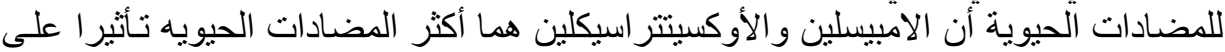

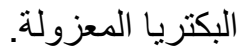




\section{SUMMARY}

The aim of the present study was to investigate vibriosis in Nile tilapia, Oreochromis niloticus, homologous and heterologous-species pathogenicity to both Nile tilapia and sharptooth catfish, Clarias gariepinus, the histopathological lesions in infected fish, and the antibiogram characters of the strains isolated. Twenty four isolates of suspected Listonella anguillarum were recovered from 16 out of 150 Nile tilapia collected from River Nile and El-Ibrahemia canal at Assiut governorate. Suspected isolates were identified as L. anguillarum according to the cell morphology, gram stain, colony morphology, biochemical characters, and enzyme activities. The pathogenicity of L. anguillarum to Nile tilapia and sharptooth catfish were investigated by an experimental challenge. Challenged fishes showed typical signs of vibriosis including general speticaemia and ascites, and accumulation of bloody exudates in the intestine. The average total mortality rates were 73.3 and $93.3 \%$ in Nile tilapia and sharptooth catfish, respectively, by the end of the challenge. The histopathological changes associated with vibriosis were mainly in the kidneys, livers, and spleens of challenged fish. The antibiotic sensitivity test for $L$. anguillarum revealed their high sensitivity to ampicillin and oxytetracycline.

Key words: Listonella anguillarum, vibriosis, Nile tilapia, hetero-species susceptibility, catfish.

\section{INTRODUCTION}

Fish vibriosis is a systemic disease of marine, estuarine, and some freshwater fishes throughout the world and is caused by bacteria of the genus Vibrio (Noga, 2010). The disease can cause significant mortality $(>50 \%)$ in fish culture (Martins et al., 2010).

At present, Listonella anguillarum is the most serious freshwater fish pathogen of family Vibrionaceae. It was first described as a fish pathogen by Bergman in 1909 as the etiological agent of red pest of eels in the Baltic Sea (Hacking and Budd, 1971). Based upon genetic studies, it was suggested that L. anguillarum should belong to a new genus, Listonella (MacDonnell and Colwell, 1985); however, this change has not been widely adopted (Noga, 2010). 
Other members of the genus vibrio have been isolated in outbreaks of vibrio in fish and shellfish including $V$. ordalli (Abd El-Gaber et al., 1997), V. parahaemolyticus (Alcaide et al., 1999), V. harveyi (Zhang and Asutin, 2000), V. vulnificus and V. damsela, (Noga, 2010). Some of which can also cause human infection such as skin ulcer, gastroenteritis or systemic infections, especially in immune suppressed individuals (Amaro and Biosca, 1996 and Won and Park 2008).

Fish affected by this classical vibriosis show typical signs of a generalized septicaemia with haemorrhages on the base of fins, exophthalmia and corneal opacity. Moribund fish are frequently anorexic with pale gills which reflects a severe anaemia. Oedematous lesions, predominantly centered on the hypodermis, are often observed (Austin and Austin, 2007).

This investigation was planned to study vibriosis in Nile tilapia, Oreochromis niloticus in Assiut city, pathogenicity of the recovered strains to Nile tilapia and the possibilities of heterologous-species pathogenicity to sharptooth catfish, Clarias gariepinus, the histopathological changes associated with the disease, and the antibiogram characters of the strains recovered.

\section{MATERIALS and METHOD}

\section{Fish collection:}

A total number of 150 alive Nile tilapia, Oreochromis niloticus, and weighing 100-500 $\mathrm{g}$ with total length of $16-30 \mathrm{~cm}$ were collected from El-Ibrahemia canal and tributaries from September 2010 to March 2011. Fish were transported immediately to the Aquatic Animals Wet Lab., Veterinary Hospital Clinic, Faculty of Veterinary Medicine, Assiut University to be examined.

\section{Clinical and bacteriological examinations of fish:}

Clinical and postmortem examinations were carried out according to Buller (2004). Aseptic bacterial isolations were made from liver, kidneys and spleen of sacrificed fish. Samples were inoculated on brain heart infusion agar supplement with $2 \% \mathrm{NaCl}$, blood agar, or thiosulphate citrate bile salt agar (TCBS agar). Inoculated media were aerobically incubated at $28^{\circ} \mathrm{C}$ for $48 \mathrm{hrs}$ (Quinn et al., 1994). Pure cultures of the isolates were identified based on phenotypic and 
biochemical characters and enzyme activities as was described in Bergey's manual of the determinative bacteriology (Garrity, 2001).

\section{Pathogenicity assay:-}

Autologous species pathogenicity of Listonella anguillarum was measured by experimental challenge of Nile tilapia, the fish species it was isolated from. Also, heterologous species pathogenicity was measured in sharptooth catfish, Clarias gariepinus.

Fish: A total number of 145 Nile tilapia with an average body weight of $50 \pm 5 \mathrm{~g}$ and total length of $15 \pm 1 \mathrm{~cm}$, and 145 sharptooth catfish weighing $100 \pm 10 \mathrm{~g}$ with total length of $20 \pm 2 \mathrm{~cm}$ were obtained from a private fish farm at Assiut Governorate. Fishes were housed in $400 \mathrm{~L}$ tanks at the Aquatic Animal Wet Lab., and 10 fish of each species were randomly examined to exclude vibriosis. Water was circulating at an exchange rate of $0.5 \mathrm{~L} / \mathrm{min}$, and daily dissolved oxygen was $6.5 \pm 0.2$ $\mathrm{mg} / \mathrm{L}$. Prior to challenge, fish were acclimated for 2 weeks in $100 \mathrm{~L}$ glass aquaria according to the protocol of maintaining bioassay fish described by Ellsaesser and Clem (1986).

Bacterial strains: Bacterial strains were kept in $\mathrm{BHI}$ broth with $15 \%$ glycerol (El-Gomhurrhia, Cairo, Egypt) at $-20^{\circ} \mathrm{C}$. A Listonella anguillarum strain (VA17) was passed through Nile tilapia via intrapretoneal (I/P) injection three times. Strain VA17 was grown on BHI agar and suspended in sterile distilled water to be diluted for experimental infection. Colony forming unit (CFU) counts of the bacterial suspensions were determined using spectrophotometery optical density values and standard plate count method (Elkamel and Thune, 2003).

Experimental challenge: In a preliminary challenge, an intraperitoneal $(\mathrm{I} / \mathrm{P})$ injection of $1 \mathrm{ml}$ of bacterial suspension of $1 \times 10^{9}$ $\mathrm{cfu} / \mathrm{ml}$ or $1 \times 10^{10} \mathrm{cfu} / \mathrm{ml}$ proved to be lethal within 7 day to all Nile tilapia or sharptooth catfish, respectively. Thus, lower concentrations of the bacterial suspensions were used for experimental challenge.

Acclimated Nile tilapia were divided into three groups with 15 fish each. The first group was intraperitoneally injected with $0.0125 \mathrm{ml}$ of bacterial suspension of $8 \times 10^{9} \mathrm{cfu} / \mathrm{ml}$, while the second group was $\mathrm{I} / \mathrm{P}$ injected with $0.0125 \mathrm{ml}$ of distilled water and the third group remained un-injected. The whole experiment was repeated three times. 
The same challenge procedures were applied to acclimated catfish, but with dose of $0.250 \mathrm{ml}$ of bacterial suspension of $4.7 \mathrm{X} 10^{9} \mathrm{cfu} / \mathrm{ml}$. Challenged fish were observed for 15 days post-infection where morbidity and mortality were recorded. Re-isolation and identification of the inoculated organism from freshly dead and moribund fish were carried out as described above.

\section{Histopathological study:-}

Specimens of the posterior kidney, liver, spleen and gills of moribund challenged Nile tilapia and sharptooth catfish were taken and fixed in $10 \%$ neutral buffered formalin. Fixed samples were gradually dehydrated, embedded in paraffin, sectioned at 4-5um. Sections were stained by Hematoxylin and Eosin, examined by light microscopy, and photographed by a digital camera (Olympus).

\section{Sensitivity test:-}

Antimicrobial susceptibility of $L$. anguillarum to different antibiotics was investigated against 6 antimicrobial agents using the disc diffusion technique as described by Finegold and Martin (1982). The inhibition zones were estimated according to the limits given by Carter and Cole (1990).

\section{RESULTS}

\section{Clinical and bacteriological examinations:-}

The clinical signs associated with naturally infected fish were haemorrhages at the mouth region and base of the fin and on the body surface of $37.33 \%$ of the fish examined. Anus was protruded and haemorrhagic in $2.67 \%$ of fish. Internally, liver in some cases was congested and friable $(5.33 \%)$, while in other cases was pale $(13.33 \%)$. Petechial to focal haemorrhages and focal necrosis were observed on the liver surface in 13.33 and $2.67 \%$ of fish examined, respectively. Kidney, gills and spleen were congested in $10.67 \%$ of fish, while gall bladder was distended and filled with bile in others $(6.67 \%)$.

Bacteriological examination resulted in recovery of 60 isolates, 24 of which were suspected to be Listonella anguillarum based on morphological and biochemical characteristics. Suspected Vibrio isolates were recovered from 16 out of 150 examined fish. Primary isolates grew well on $\mathrm{BHI}$ agar with $2 \% \mathrm{NaCl}$ giving creamy, convex, 
glistening colonies. On TCBS agar, colonies were yellow and in two cases green raised convex colonies. Colonies were small, convex, translucent, and greenish on blood agar.

Suspected isolates were gram-negative, motile rod shape curved bacilli. All suspected isolates tolerated BHI media supplemented with up to $6 \% \mathrm{NaCl}$. Results of the biochemical characters and enzyme activities of suspected isolates are shown in Table (1). Organ susceptibility of Nile tilapia to L. anguillarum infections are shown in Table (2).

\section{Experimental infection:}

Moribund Nile tilapia in the challenged groups exhibited similar signs to those of naturally infected fish and characterized by excessive mucus production covering the body surface that given dark coloration of fish (26.67\%). Signs of generalized septicemia were observed such as petechial haemorrhage in the mouth region and on the fins in $30 \%$ of fish. Gills, kidneys, spleen and liver were congested in many fish (46.67\%). Petechial and focal haemorrhages on the surface of the liver and enlargement of the spleen were seen in $13.33 \%$ of fish challenged (Fig.1). As a typical sign of vibriosis, intestine of some fish (13.33\%) was filled with bloody serous fluid. The average mortality rate was 66.67 and $73.3 \%$ by the end the first and second week post-challenge, respectively. Re- isolation of the bacteria in pure culture was done from freshly dead and moribund fish. There was no mortality or clinical signs of infection in both of the control groups.

Experimentally challenged sharptooth catfish with L. anguillarum showed increase of mucus production and ulceration and fin rot in $46.67 \%$ of the fish challenged. In some cases inflammation of the vent was observed (20\%). More than half of the challenged fish $(53.33 \%)$ had ascitis in the abdominal cavity of bloody exudate. Liver and kidney were congested in $66.67 \%$ of the challenged fish, while spleen was darker than normal and larger in size in $60 \%$ of the fish. Congestion of the blood vessels of stomach and gonads were also observed. Thirty percent of challenged fish had the intestine filled with bloody exudate (Fig. 2). By the end of first week post-infection, the average mortality rate was $66.67 \%$, while it was $93.3 \%$ by the end of the second week. Fish of both control groups remained alive and showed no signs of infection by the end of challenge. 


\section{Histopathological examination:}

The most profound histopathological changes in this study were found to be mainly in the liver and posterior kidney of both challenged Nile tilapia and catfish. Tilapia livers showed circumscribed welldefined area of vacuolation with well-defined clear outlines. Also, livers showed well expressed peri-vascular hepatic necrosis expressed by cytolysis and karyorehexis of the hepatocytes nuclei (3A). On the other hand, gills of tilapia had lamellar fusion and hyperplasia of the interlamellar epitrhelium. The livers of challenged catfish showed marked disorganization of the hepatic lobules. Moreover, hepatolysis with pyknosis or ghost-like appearance of the hepatocytes nuclei were also observed. Central veins of the hepatic lobules were hyperemic with few perivascular leukocytes (Fig. 3B). The catfish spleens had lymphocyic exhasustion, lysis with marked decrease of the lymphocytes forming the splenic corpuscles (Fig. 3C).

The catfish posterior kidney showed massive extravasated red blood cells in the interstitial connective tissue intermingled with leukocytes. Moreover, severe necrosis of the epithelium lining both the proximal and distal convoluted tubules were observed (Fig. 3D). These necrotic changes were expressed by sloughing of the epithelium lining and resulted in marked separation of the epithelium from the basement membranes of the tubules. There were aggregations of acidophilic material in the lumen of the distal convoluted tubules (Fig. 3D). The glomeruli of the posterior kidney showed hyperemia of the capillary tuft as well as obliteration of the bowman's capsules.

\section{Antiiogram sensitivity:}

Isolates of L. anguillarum in the present study were sensitive to ampicillin and oxytetracycline, but resistant to erythromycine, tobramycin, neomycin and sulphamethazole. 
Table 1: Cultural and biochemical characteristics of the suspected Listonella sp. $(\mathrm{n}=24)$.

\begin{tabular}{|c|c|}
\hline Test & Result \\
\hline Oxidase & + \\
\hline Calatase & + \\
\hline Motility & + \\
\hline $\mathrm{O} / \mathrm{F}$ test & $+/+$ \\
\hline Simmon citrate & + \\
\hline Indole & $\mathrm{V}$ \\
\hline Nitrate reduction & + \\
\hline Vogus-Proskauer & + \\
\hline Methyl red & - \\
\hline TSI reaction & $\mathrm{A} / \mathrm{A} \quad \mathrm{K} / \mathrm{A}$ \\
\hline $\mathrm{H}_{2} \mathrm{~S}$ production & - \\
\hline Urease & - \\
\hline Lysine decarboxilase & - \\
\hline Ornithine decarboxylase & - \\
\hline Arginine decarboxylase & + \\
\hline Growth on: & \\
\hline TCBS & Yellow / green \\
\hline Blood agar & Hemolysis \\
\hline $\mathrm{BHI}+2 \%$ & + \\
\hline $4 \%$ & + \\
\hline $6 \%$ & + \\
\hline $8 \%$ & - \\
\hline $10 \%$ & - \\
\hline Growth at : $25^{\circ} \mathrm{C}$ & + \\
\hline $37^{\circ} \mathrm{C}$ & + \\
\hline Acid production from: - & \\
\hline Glucose & + \\
\hline Sorbitol & + \\
\hline Arabinose & $\mathrm{V}$ \\
\hline Lactose & $\mathrm{V}$ \\
\hline Sucrose & + \\
\hline Fructose & + \\
\hline Mannitol & $\mathrm{V}$ \\
\hline
\end{tabular}

$(+)$ positive, (-) negative, and (V) variable

Table 2: Organ susceptibility of $L$. anguillarum

\begin{tabular}{|c|c|c|}
\hline Organ & NO. & \% \\
\hline Liver & 4 & 16.67 \\
Kidney & 6 & 25 \\
spleen & 14 & 58.33 \\
\hline Total & 24 & 100 \\
\hline
\end{tabular}




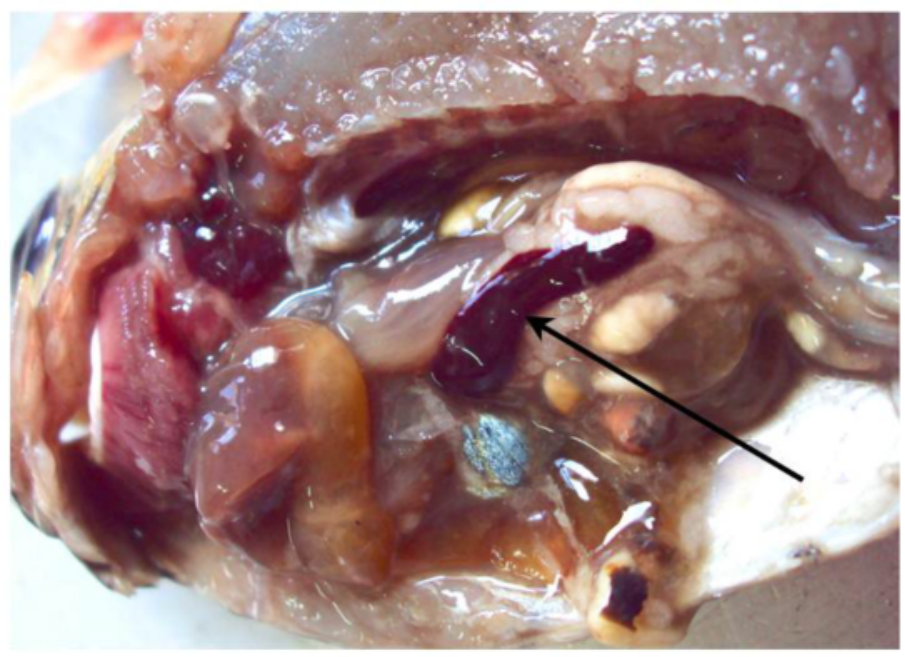

Fig. 1: Nile tilapia, Oreochromis niloticus, challenged with intraperitoneal injection of Listonella anguillarum showing enlargement and rounding of the edges of the spleen.

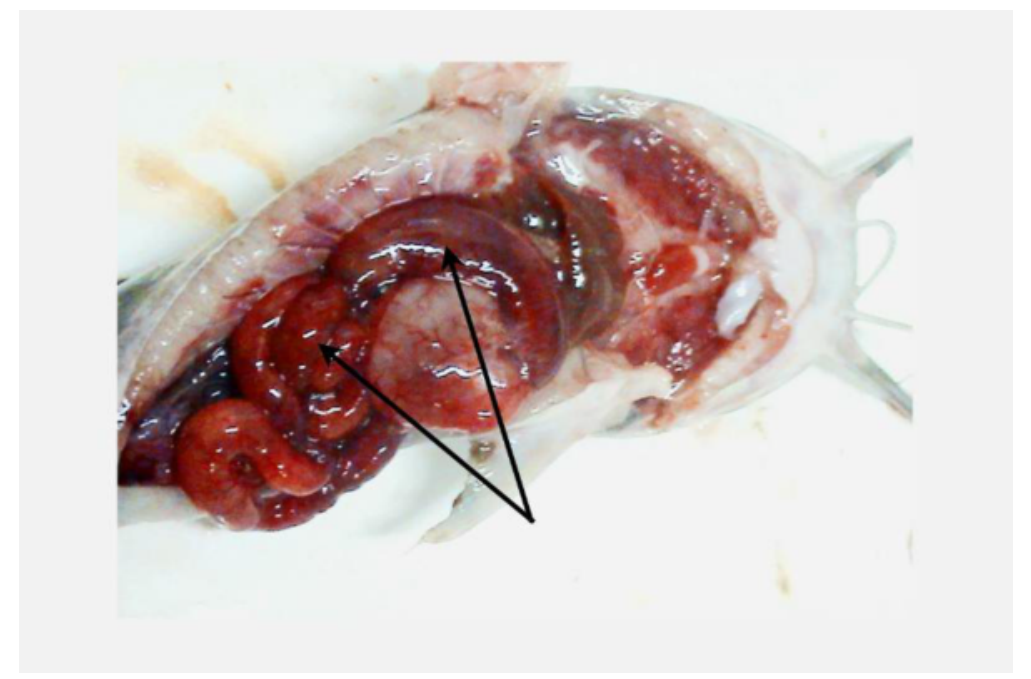

Fig. 2: Sharptooth catfish, Clarias gariepinus, challenged with intraperitoneal injection of Listonella anguillarum showing bloody fluids filling the intestine. 

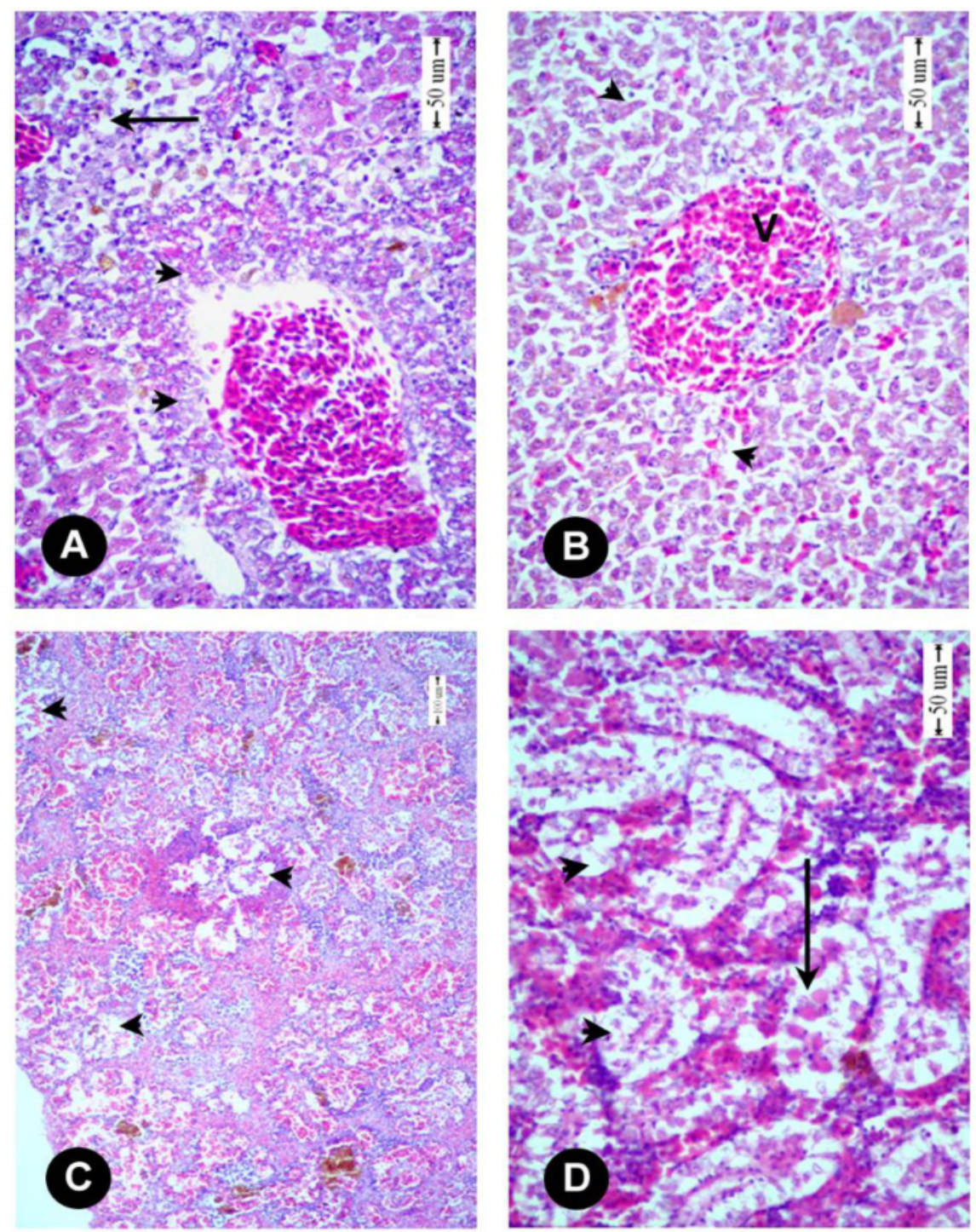

Fig. 3: Nile tilapia, Oreochromis niloticus, or sharptooth catfish, Clarias gariepinus, challenged with intraperitoneal $(\mathrm{I} / \mathrm{P})$ injection of Listonella anguillarum. (A): Liver of Nile tilapia showing pericentral necrosis of hepatocytes (arrow heads) as well as hepatolysis (arrow). (B): Liver of sharptooth catfish showing hyperemia of the central vein (V) with hepatocellular necrosis (arrow heads). (C): Spleen of sharptooth catfish showing severe necrosis of the white pulp (arrow heads). (D): Kidney of catfish showing severe necrosis of both proximal and distal convoluted tubules (arrow heads) and accumulation of acidophilic proteinicious material also noticed (arrow). H\&E. 


\section{DISCUSSION}

The aim of the current study was to investigate vibriosis in Nile tilapia, homologous and heterologous-species pathogenicity of the strains isolated, in addition to the antibiogram characters of such strains. Vibriosis is a serious infectious disease among marine and freshwater fish. Listonella anguillarum is the most prevalent causative agent of vibriosis and is the best studied fish pathogens of Vibrionacae (Spanggaard et al., 2000). Although L. anguillarum is not an obligate parasite, yet it is a primary pathogen of fishes, and if present in or around fishes, it will sooner or later cause diseases (Post, 1987).

The phenotypic and culture characters of the colonies and the staining properties of the bacteria isolated from Nile tilapia, O. niloticus, suggested that the suspected isolates are L. anguillarum as was described by Austin and Austin (2007); Mostafa et al. (2010) and Noga (2010). The tolerance to $\mathrm{NaCl}$ of $L$. anguillarum in this study was up to $6 \%$, while it could not grow on media with $8 \% \mathrm{NaCl}$. These results are in accordance with those of Inglis et al. (1993) who recorded that L. anguillarum grew on 3\%, but not on $7 \%$ sodium. On the other hand, Abd El-Gaber et al. (1997) reported that vibrio isolates grew on media containing $4-9 \%$ sodium chloride.

Results of the current study indicated that $16(10.67 \%)$ out of the 150 collected fish were naturally infected with $L$. anguillarum. The prevalence of vibriosis recorded in the present study is low compared to a prevalence of $42.5 \%$ that was reported in both Qarun and Manzala lakes (Abd El-Gaber et al., 1997), and to 62\% that was reported in ElQassiem area Saudia Arabia (Shahat and Emehana, 2000). Such results may be attributed to species differences, in addition to low salinity in River Nile and El-Ibrahemia canal, as vibriosis is more prevalent in brackish and marine water (Noga, 2010) due to the halophilic nature of the causative agent, $L$. anguillarum. On the other hand, vibriosis was reported at a relatively lower rate similar to that recorded in the current study, as $13.13 \%$ (Abbass and Sobhy, 2005) and $17.55 \%$ in lake Qarun and Suez Gulf (Mostafa et al., 2010).

The organ susceptibility study revealed that the spleen is the target organ where $L$. anguillarum from Nile tilapia. Vibriosis systemic infections often localize in iron-rich filtering organs, such as spleen and kidney (Noga, 2010). It was reported that the bacteria are initially found in the spleen, but, as the number of cells in this organ increased, the 
bacteria appeared in the kidney, and by the time of death, most tissues were septic (Nelson et al., 1985).

Results of experimental challenge in the present study proved that L. anguillarum isolated from naturally infected Nile tilapia is pathogenic to both healthy tilapia (autologous species) and to sharptooth catfish (heterologous species). Interestingly, the pathogenesis and the extension of lesions were more intense in sharptooth catfish, the heterologous susceptible species. These findings raise questions about the original host, most susceptible host, and source of infections, inter-species transmission, and whether Nile tilapia is main freshwater reservoir species.

Postmortem examination of experimentally infected Nile tilapia and sharptooth catfish showed septicemic lesions as congestion of internal organs and bloody exudates in the intestine. These lesions were nearly similar to those previously reported in case of acute vibriosis (Noga, 2010 and El-Sunaiher et al., 2010). The pathogenicity of $L$. anguillarum to fish may be attributed to extracellular toxins and enzymes produced by the bacterium (Nottage and Birkeck, 1987). Vibrio produced hemolysin which causes destruction of the blood vessels (Hjeltnes and Roberts, 1993), in addition to extracellular products with protease activities (Pedersen and Larsen, 1999).

Treatment of vibriosis has primarily been directed towards the use of antibiotics. In the present study, $L$. anguillarum were sensitive to oxytetracycline as was stated by Austin and Austin (2007), while, it was resistant to erythromycin and sulphamethazole as was reported by Noga (2010).

Histopathological changes associated with natural and experimental infection of vibriosis in Lates calcarifer were described mainly in the livers, spleen, mesonephros, and gills where severe tubular necrosis and hematopiotic hyperplasia of the posterior kidneys were reported (Azad et al., 2004). In the present study, similar changes were reported and manifested by the interstitial hemorrhage and tubular necrosis, and hyperemia of the capillary tufs of the glomeruli. These changes were consistent and suggested the acute phase pathogenesisrelated manifestations of vibriosis.

Azad et al. (2004) reported that hony-comb vacuolated area in the liver of fish naturally infected with vibriosis, but not in experimentally infected fish. In the present study, the necrotic changes were more 
pronounced in catfish livers compared to tilapia, while, tilapia livers had the vacuolated appearance which could be fatty change. This difference could be explained that the immune response of tilapia is different than that of sharptooth catfish. This presumption can be supported by the changes observed in the spleen of sharptooth catfish which had lymphocytic exhaustion in the splenic corpuscles. Gill alterations observed in this study and expressed by lamellar fusion and hyperplasia of the interlammelar epithelium were similar to those described by Azad et al. (2004). The histopathological changes observed in the present study could be confined to Vibrio Spp. and reflect the acute phase pathogenesis-related response against vibriosis.

In conclusion, results obtained in this study demonstrate that strains of $L$. anguillarum isolated from Nile tilapia are pathogenic and can produce active infections in both Nile tilapia and sharptooth catfish. Further studies should address the epizootiology, pathogenesis, and control of vibriosis in Nile tilapia and sharptooth catfish.

\section{REFERENCES}

Abbass, A.A. and Sobhy, M.M. (2005): Vibriosis in some fishes: Molecular characterization of fish pathogenic vibrios. Vet. Med. J. Giza.4: 911-923.

Abd El-Gaber, G.; Naguib, M. and Abd El-Aziz (1997): Vibrio species infection to Oreochromis niloticus and Mugil cephalus: sodium chloride tolerance, pathogenicity, serological relatedness and antibiograms sensitivity of recovered vibrios. Vet. Med. J., Giza. 45(1): 87-99.

Alcaide, E.; Amaro, C.; Todoli, R. and Oltra, R. (1993): Isolation and characterization of Vibrio parahaemolyticus causing infection in Iberian toothcarp Aphanius iberus. Diseases of Aquatic Organisms.35: 77-80.

Amaro, C. and Biosca, E.G. (1996): Vibrio vulnificus biotype 2, pathogenic for eels, is also an opportunistic pathogen for humans. Appl. Environ. Microbiol. 62: 1454-1457.

Austin, B. and Austin, D.A. (2007): Characteristics of the pathogens: Gram-negative bacteria, In Bacterial Fish Pathogens: disease of farmed and wild fish fourth edition. Springer-Praxis. Praxis Publishing Ltd., Chichester, UK. 
Azad, I.S.; Thirunavukkarasu, A.R.; Kailasam, M. and Rajan, J.S.S. (2004): Virulance and histopathology of Vibrio angullarum-Like (VAL) Bacterium isolated from produced juveniles of Lates calcarifer. Asian Fisheries Science 17: 101-110

Buller, N.B. (2004): Bacteria from fish and other aquatic animals: A practical identification manual. CABI Publishing, Cambridge.

Carter, G.R. and Cole, J.R. (1990): Diagnostic procedure in veterinary bacteriology and mycology. $5^{\text {th }}$ ed. Academic Press.

Elkamel, A.A. and Thune, R.L. (2003): Invasion and replication of Photobacterium damselae sub species piscicida in fish cell lines. J. Aquatic Animal Health, 15: 167-174.

Ellsaesser, C.F. and Clem, L.W. (1986): Hematological and immunological changes in channel catfish by handing and transport. Journal of fish biology. 28: 511-521.

El-sunaiher, A.E.; Abdelnasser, S.S.; Ibrahim and Ali A. Al-Salamah (2010): Association of vibrio species with disease incidence in some cultures fishes in Kingdom of Saudi Arabia. World applied sciences journal.8 (5): 653-660.

Finegold, S.M and Martin, W.J. (1982): Diagnostic Microbiology. $6^{\text {th }}$ Ed. C.V. Mosby, USA.

Garrity, G.M. (2001): Bergey's manual of systematic bacteriology. New York: Springer-Verlag.

Hacking, M.A. and Budd, J. (1971): Vibrio infection in tropical fish in a freshwater aquarium. Journal of wildlife diseases.7: 273-280.

Hjeltnes, B. and Roberts, R.J. (1993): Bacterial diseases of fish, Newyork, Halsted press, Pp.109-121.

Inglis, V.; Roberts, R.J. and Bromage, N.R. (1993): Bacterial diseases of fish. Oxoford Blackwell scientific Publications, London.

MacDonnell, MT. and Colwell, RR. (1985): Phylogeny of the Vibrionaceae and recommendations for two new genera, Listonella and Shewanella. Systemic and Applied Microbiology 6: 171-182.

Martins, M.; Mourino, J.; Fezer, G. and Buglione Neto, C. (2010): Isolation and experimental infection with Vibrio alginolyticus in the sea horse, Hippocampus reidi Ginsburg, 1933 (Osteichthyes: Syngnathidae) in Brazil. Brazil. J. Biol. 70.

Moustafa, M.; Mohamed, L.A.; Mahmoud, M.A.; Soliman, W.S. and ElGendy, M.Y. (2010): Bacterial infections affecting marine fishes in Egypt. Journal of American Science. 6 (11): 603-612. 
Nelson, J.; Rohovec, J.S. and Fryer, J.L. (1985): Location of Listonella anguillarum in tissues of infected rainbow trout (Salmo gairdneri) using the fluorescent antibody technique. Fish pathology. 20: 229-235.

Noga, E.J. (2010): Fish disease, Diagnosis and treatment.Mosby, St. Louis, MO, USA.

Nottage, A.S. and Birkbeck, T.H. (1987): Production of protinase during experimental infection of Osreea edulis L. larvae with Vibrio alginolyticus and antigenic relation ship between protinase produced by marine vibrios pathogenic for fish and shellfish. J. Fish Dis. 10: 265-273.

Post, G. (1987): Textbook of fish health. T.F.H. Publication Inc. for revised and expanded Edition, 41-44.

Quinn P.J.; Carter, M.E.; Markey, B.K. and Carter, G.R. (1994): Clinical veterinary microbiology. Published by Welfe publishing.

Shahat, A.A. and Mehana, E.E. (2000): Listonella anguillarum as a stress-borne pathogen in cultured freshwater fish. Vet. Med. J., Giza. 48 (1) 1-6.

Spanggaard, B.; Huber, I.; Nielsen, J.; Nielsen, T. and Gram, L. (2000): Proliferation and location of Listonella anguillarum during infection of rainbow trout, Oncorhynchus mykiss (walbaum). Journal of fish diseases. 23: 423-427.

Zhang, X.H. and Austin, B. (2000): Pathogenicity of Vibrio harveyi in salmonids. J. Fish Dis. 23: 93-102. 